\title{
Chemical composition and functional properties of snake gourd (Trichosanthes cucumerina) seed flour
}

\author{
Yusuf,A. A.*, Folarin, O. M. and Bamiro, F. O. \\ Department of Chemistry \\ University of Agriculture, Abeokuta \\ P. M. B. 2240, Abeokuta, Nigeria. \\ * Address for correspondence E-mail: yusufaazooo@yahoo.com
}

ABSTRACT

\begin{abstract}
The chemical composition and functional properties of snake gourd (Trichosanthes cucumerina) seed flour were studied. The effects of sample-solvent ratio, nature and concentration of solubilizing agents, extraction time as well as sample pre-treatment on protein solubility were studied. The crude protein in the flour (N\% x 6.25) was determined to be $30.18 \%$. The predominant mineral elements were potassium $\left(121.60 \mathrm{mg} 100^{-1} \mathrm{~g}\right)$ and phosphorus $\left(135.0 \mathrm{mg} 100^{-1} \mathrm{~g}\right)$. Other elements found in fairly high amounts are Sodium, Magnesium and Zinc. Nitrogen solubility was $\mathrm{pH}$ dependent with a minimum
\end{abstract}

value of $10 \%$ at $\mathrm{pH} 4.0$ and a maximum of $40 \%$ at $\mathrm{pH}$ 11.0. Other functional properties, water and oil absorption, foaming and least gelation capacities, are comparable with most seeds and nuts reported in the literature. Of all the protein solubilizing agents tested, $0.03 \mathrm{M} \mathrm{NaOH}$ solution at sample-solvent ratio of 1:10 and extraction period of 20 mins was found to be the most effective solubilizing agent for the snakegourd seed flour protein.

Key words: Composition, functional properties, snake gourd seed.

\section{INTRODUCTION}

$\mathbf{T}$ richosanthes cucumerina var.anguina (L) Haines is a cucurbitaceous vegetable that is cultivated in gardens in Nigeria. The plant is well adapted to growth in high rainfall areas. It does not withstand dry soil conditions and requires a plentiful reserve of moisture in the soil; hence it grows in limited areas of the tropics and is often classified as minor cucurbitaceous vegetable (Martin, 1987). It is a plant with creeping stems and tendrils. The fruits are cylindrical, very long and narrow at both ends, green to white as much as $1.2 \mathrm{~m}$ long and about $5-7 \mathrm{~cm}$ in diameter. (Dupriez and De-Leener, 1989). The flesh is red and fibrous when matured. The pulp of the ripe fruits is used in sauces and is good substitute for tomato paste. The seeds are flat, grew-brown, sculptured, and narrow at one end and about $1.7 \mathrm{~cm}$ long (Tindall, 1983). The edible part of the immature fruit is $86-98 \%$ per $100 \mathrm{~g}$ edible portions, it contains water $94 \mathrm{~g}$, protein $(0.6 \mathrm{~g})$, fat $(0.3 \mathrm{~g})$, carbohydrate $(4 \mathrm{~g})$, fibre $(0.8 \mathrm{~g}), \mathrm{Ca}$ (26mg), Fe (0.3mg), P (20mg), Vitamin B1 (0.02mg), Vitamin B2 0.03ng, Niacin $0.3 \mathrm{mg}$, Vitamin C $(12 \mathrm{mg})$, energy value $70 \mathrm{~kJ}$ (Siemonsma and Piluck, 1993). The fruits become inedible upon ripening, they taste bitter and developed hardened fibro vascular bundles. Fruits of the wild forms are very bitter and inedible. They are used in traditional medicine as a purgative. The use of the pulp of ripe fruits as a substitute for tomato paste is the major use of snakegourd known. There are limited reports on the chemical composition and nutritive value of snakegourd seed. Information on its functional properties is lacking. Essential in determining potential uses for snakegourd seed flour, is the 
identification and improvement of its functional properties. This study was carried out to examine the chemical composition and functional properties of snakegourd seed flour. The potential food uses for the flour were evaluated by laboratory tests for protein solubility, water and oil absorption capacities, gelation foaming as well as emulsion capacity.

\section{MATERIALS AND METHODS Sample Collection and Pre-treatment}

Ripe fruits of the plant were collected in Abeokuta. The seeds were removed from the pulp and air-dried in the laboratory. Seeds were deshelled to obtain the cotyledons which were grinded in a mechanical crushing mill. Oil was extracted from the sample in a soxhlet extractor with petroleum ether $\left(\mathrm{bp} 40^{\circ}-60^{\circ} \mathrm{C}\right)$. The defatted sample was used for subsequent analyses.

\section{Seed flour}

The defatted sample was dried in oven at $90^{\circ} \mathrm{C}$ for $10 \mathrm{~min}$ and then milled to pass through a $0.5 \mathrm{~mm}$ sieve. The sample was kept in dry polythene sack and stored in the refrigerator until ready for use.

\section{Sample Analysis \\ Chemical Analysis}

Procedures for determination of iodine value (Wij's), saponification number, acid value, peroxide value and refractive index of the oil were those recommended in the official methods of AOAC (1984).

Crude Protein (N\% x 6.25) was determined by micro kjeldahl method. Crude fibre was determined by weighing $2 \mathrm{~g}$ of defatted sample into a flask and TCA digestion reagent added and refluxed for 40min. The digest, after cooling was filtered and the residue washed with hot water and then with ethanol before drying in oven at $105^{\circ} \mathrm{C}$. The residue was then placed in a preweighed crucible and weighed. This was then preashed and ashed in a furnace. The weight after ashing was taken and the difference in weight was used to calculate the crude fibre. For mineral elements determination, the residual ash from ash content determination was dissolved in $5 \mathrm{ml}$ conc. $\mathrm{HNO}_{3}$. This was transferred quantitatively into a $250 \mathrm{ml}$ volumetric flask and $10 \mathrm{ml}$ of Lanthanum Chloride added to act as ionisation suppressant and the solution was made up to the mark with deionised water. The resulting solution was used directly for the analysis. $\mathrm{K}^{+}, \mathrm{Na}^{+}$and $\mathrm{Ca}^{2+}$ were determined using PFP7 Jenway flame photometer while $\mathrm{Mg}^{2+}, \mathrm{Fe}^{2+}, \mathrm{Zn}^{2+}, \mathrm{Cu}^{2+}, \mathrm{Pb}^{2+}$, $\mathrm{Co}^{2+}$ and $\mathrm{Mn}^{2+}$ were determined by Pye-unicam SP-9 atomic absorption spectrophotometer using appropriate hollow cathode lamp. Phosphorus was determined by phospho-molybdate method. The determination of carbohydrate was by difference.

\section{Functional Properties} Nitrogen Solubility

Protein solubility index was determined in the $\mathrm{pH}$ range $1-12$ using either $0.1 \mathrm{M} \mathrm{HCl}$ or $0.1 \mathrm{M} \mathrm{NaOH}$ solution. The flour sample $(1 \mathrm{~g})$ was dispersed in 50ml distilled water and stirred with a magnetic stirrer at laboratory temperature. The suspension was then centrifuged at $3500 \mathrm{~g}$ for $30 \mathrm{~min}$ and the nitrogen in the supernatant was estimated by the microkjeldahl method. The nitrogen extracted was expressed as a percentage of the flour nitrogen. The protein concentrate was precipitated out of solution at $\mathrm{pH} 4$.

\section{Water and Oil Absorption Capacity}

These were determined as described by Beuchat (1977). The flour (1g) was mixed with $10 \mathrm{ml}$ distilled water for water absorption and $10 \mathrm{ml}$ of oil for oil absorption in a Kenwood blender for $30 \mathrm{sec}$. The samples were then allowed to stand at $25^{\circ} \mathrm{C}$ for $30 \mathrm{~min}$ and centrifuged at $3500 \mathrm{~g}$ for $30 \mathrm{~min}$. The supernatant was decanted and discarded. The weight of water or oil absorbed by $1 \mathrm{~g}$ of flour was calculated and expressed as water or oil absorption capacity. 


\section{Emulsion Capacity}

The emulsion was prepared according to the method of Beuchat et al (1975). 2g sample and $23 \mathrm{ml}$ of distilled water were blended at room temperature for $30 \mathrm{sec}$ in a Kenwood blender at high speed. After complete dispersion, groundnut oil was added at a rate of $0.4 \mathrm{ml} / \mathrm{s}$ from a burette and blended until phase separation emulsion break point occurred. The amount of oil added up to this point was interpreted as emulsion capacity of the sample. The emulsion capacity was determined and the value expressed in grams of oil emulsified by $1 \mathrm{~g}$ flour.

\section{Foaming Capacity}

Flour sample $(2 \mathrm{~g})$ and $100 \mathrm{ml}$ distilled water were blended in a Kenwood blender at high speed for $5 \mathrm{~min}$ and the dispersion poured into $250 \mathrm{ml}$ measuring cylinder. The volume of foam at $30 \mathrm{sec}$ after whipping was expressed as the foaming capacity according to Lawhon et al (1972).

\section{Gelation}

This was done by the method of Coffman and Garcia (1977). Sample suspensions 2 $20 \%(\mathrm{w} / \mathrm{v})$ were prepared in $5 \mathrm{ml}$-distilled water. The tubes containing these. Suspensions were heated in boiling water for $1 \mathrm{hr}$ followed by rapid cooling under cold running tap water. The tubes were then further cooled for $2 \mathrm{~h}$ at $7^{\circ} \mathrm{C}$. The least gelation concentration (LGC) was determined as that concentration when the sample from the inverted tube did not fall or slip.

\section{RESULTS AND DISCUSSION}

The results of the chemical composition of the seed and protein concentrate are shown in Table 1. Table 2 shows physicochemical characteristics of the seed oil and Table 3 shows the mineral elements composition of the seed flour. The moisture content of the seed, $3.13 \%$ is low compared with values reported for melon seed (5.6\%) and water melon (5.7\%) (Ige et al 1984; Osagie and Odutuga, 1986). The ash content of the seed is quite high $(2.93 \%)$ and this may make it unsuitable for animal feed production. It has been estimated that ash content in most nuts, seeds and tubers should fall in the range $1.0-2.5 \%$. Crude protein in the seed averaged $30.1 \%$ which is comparable with those of soybean $(35.1 \%)$ and melon seed $(33.3 \%)$ (Achinewhu 1983). On extraction with petroleum ether, the seeds yielded $47.7 \%$ of dark brown oil. This yield is comparable with most oilseeds and nuts. melon seed $(51.1 \%)$, cashew nut $(48.1 \%)$, groundnut $(45.3 \%)$. (Table 1$)$

The mineral elements composition of the seed as calculated in $\mathrm{mg} .100^{-1} \mathrm{~g}$ of seed dry weight is shown in Table 3. Of the metal elements determined, potassium was the highest (121.6) while copper and manganese were the least (0.31). The amount of phosphorus determined was (135.0) (Table 3).

The functional properties of seed flour and protein concentrate are presented in Table 4.

The nitrogen solubility profile ranges from pH 1 to 12 .Nitrogen solubility was observed to be $\mathrm{pH}$ dependent. The minimum solubility occurred at $\mathrm{pH} 4$. The snakegourd flour had a minimum nitrogen solubility of $10 \%$ at $\mathrm{pH} 4$. This is comparable with soy flour that has minimum nitrogen solubility of $10 \%$ at $\mathrm{pH} 4.5$. (Smith and Cycle, 1972)

Based on nitrogen solubility profile, snakegourd seed proteins were acidic in nature. On either side of this $\mathrm{pH}$, the Nitrogen solubility increased and reached a maximum of $40 \%$ at alkaline pH. (Osagie and Odutuga 1986).

The water and oil absorption capacity of both flour and protein concentrate is presented in Table 4 . The water absorption capacity of the flour and protein concentrate is $130 \%$ and $162 \%$ respectively. The values obtained are comparable with values reported in the literature for most nuts and seeds: soy flour (130\%); pigeon pea flour $(138 \%)$, cowpea flour $(100 \%)$. The results 
revealed that the protein concentrate absorbed more water than the flour. The oil absorption capacity of the flour and protein concentrate are $54 \%$ and $115 \%$ respectively. The data showed that oil absorption capacity of the protein concentrate is higher than that of the flour. The value reported for the flour in this work is lower than the values reported in the literature for most nuts and seeds: Pigeon pea flour $(89.7 \%)$; pumpkin seed flour, $87 \%$ and Gourd seed $(6 \%)$; wheat flour, $84.2 \%$ and Soy flour $(84.4 \%)$ (Olaofe et al 1994).

The emulsion capacities of the flour and protein concentrate are 450 and $690 \mathrm{ml}$ oil/g dry sample respectively (Table 4 ). The protein concentrate has higher emulsion capacity than the flour. This observation may be attributed to the presence of carbohydrates and fibres in the flour. The same trend had been reported by Ramanatham et al, 1978, who concluded that the presence of carbohydrate and fibre in groundnut flour have adverse effect on emulsion capacity. (Romanatham et al 1978).

Gelation is an aggregation of denatured molecules and protein concentration, especially globulin fraction, and interactions between proteins, carbohydrates and lipids have been reported to be responsible for the gelation capacity of legume and oil seed protein. (Fleming et al 1975). The seed flour has least gelation capacity of $18 \%$ while the protein concentrate has least gelation capacity of $30 \%$. The value reported for the seed flour is comparable with values reported for cowpea flour $(16.0 \%)$; peanut flour $(10.0 \%)$. This study showed that snakegourd seed flour required a lower concentration for gel formation than most oil seeds and legume flours and may find useful applications in food systems such as sausage emulsion, sauces that require thickening and gelling. The results observed for least gelation concentration corroborates those observed for foaming capacity.
The foaming capacities of the flour and protein concentrate are $47 \%$ and $78 \%$ respectively. The value reported for the flour is comparable with values reported for most oil seeds. Gourd seed(40\%), pumpkin seed (50\%) and melon seed (40\%). Grahams and Phillips 1976, linked good formability with flexible protein molecules that can reduce surface tension while highly ordered globular protein, which is relatively difficult to surface denature give low foamability. One may therefore suggest that snakegourd protein may contain high concentration of flexible protein.

Proteins are usually linked to functional properties and their solubilization and precipitation in plant materials are affected by so many factors. Some of these are sample solvent ratio, nature and concentration of extractant, extraction time and sample pretreatment. Effect of some of these factors was investigated on the protein of snakegourd seed flour.

Table5 presents the effect of flour-solvent ratio on the solubilization and precipitation of snakegourd seed flour protein. Of the three solubilizing agents used, $0.03 \mathrm{M} \mathrm{NaOH}, 0.03 \mathrm{M}$ $\mathrm{Na}_{2} \mathrm{SO}_{3}$ and $0.03 \mathrm{M} \mathrm{Ca}(\mathrm{OH})_{2}$, the flour-solvent ratio of $1: 10(\mathrm{w} / \mathrm{v})$ was found to be most effective for each. For $\mathrm{NaOH}, \%$ solubilized protein is 95.12 while \% precipitated protein is $80.54 \%$. In $\mathrm{Na}_{2} \mathrm{SO}_{3}, 89.25 \%$ of protein was solubilized while $74.10 \%$ was precipitated. $80.23 \%$ protein was solubilized in $\mathrm{Ca}(\mathrm{OH})_{2}$ and $65.42 \%$ protein was precipitated.

Table 6 presents the effect of nature and concentration of extractants. Among the protein solubilizing agents tested, $0.03 \mathrm{M} \mathrm{NaOH}$ was the most effective solubilizer of snakegourd protein. The \% protein solubilized is 95.12 while \% protein precipitated is 80.54 . Other solubilizing agents, $\mathrm{Na}_{2} \mathrm{SO}_{3}$ and $\mathrm{Ca}(\mathrm{OH})_{2}$ were also found to be most effective at $0.03 \mathrm{M}$ concentration but the 
$\%$ of protein solubilized and precipitated in each solvent was lower than in $\mathrm{NaOH}$ at the same concentration.

It was observed that $0.03 \mathrm{M} \mathrm{Na}_{2} \mathrm{SO}_{3}$ is as effective as $0.03 \mathrm{M} \mathrm{NaOH}$ for the extraction of snakegourd protein (Table6). The use of $0.03 \mathrm{M}$ $\mathrm{Na}_{2} \mathrm{SO}_{3}$ has some advantages according to Cheftel et al., 1989. Extraction conditions are milder ( $\mathrm{pH}$ 10.5) and $\mathrm{Na}_{2} \mathrm{SO}_{3}$ inhibits polyphenol oxidation, avoiding the subsequent reaction between proteins and oxidized polyphenols (Cheftel et al 1989). This reaction is responsible for the light brown colour of protein isolate extracted with $0.03 \mathrm{M} \mathrm{NaOH}$ compared to the white colour of protein isolate obtained with $0.03 \mathrm{M} \mathrm{Na}_{2} \mathrm{SO}_{3}$.

Table 7 presents the effect of extraction time on protein solubilization and precipitation. For the three solubilizing agents at $0.03 \mathrm{M}$ concentration, maximum extraction of protein was achieved at an average of $20 \mathrm{~min}$ of agitation. After 20min, protein solubility lowered and this may be due to the fact that proteins become less soluble as a result of denaturation.

Table 8 presents the effect of flour treatment on protein solubilization and precipitation. There was no difference in the amount of protein solubilized and precipitated from both defatted and undefatted flour using the three solubilizing agents.

\section{CONCLUSION}

The study has shown that snakegourd seed (Trichosanthes cucumerina) is an oil seed with appreciable high levels of crude protein and ash. The functional properties of the seed flour have shown the potential industrial applications of the seed particularly in the food systems that require thickening and gelling.

Table1 : Proximate composition of seed flour and protein concentrate.

\begin{tabular}{lcc}
\hline & \multicolumn{2}{c}{$\%$ Composition } \\
\hline Parameter & Seed Flour & Protein concentrate \\
\hline Moisture & $3.13 \pm 0.39$ & $2.54 \pm 0.01$ \\
Ether Extract & $47.70 \pm 2.05$ & N.D \\
Crude Protein & $30.18 \pm 0.80$ & $88.14 \pm 0.16$ \\
Crude Fibre & $8.00 \pm 0.03$ & $2.03 \pm 0.03$ \\
Ash & $2.93 \pm 0.05$ & $6.00 \pm 0.12$ \\
Carbohydrate & $7.59 \pm 0.02$ & $1.00 \pm 0.01$ \\
\hline
\end{tabular}

ND $=$ Not Detectable

Data are means of triplicate determinations \pm standard errors. 
Table 2 : Physicochemical characteristics of the seed oil.

\begin{tabular}{ll}
\hline Parameter & \\
\hline Refractive ndex $\left(40^{\circ} \mathrm{C}\right)$ & 1.4690 \\
Density $\left(40^{\circ} \mathrm{C}\right)$ & $0.864 \mathrm{~cm}^{-3}$ \\
Iodine value & $38.0 \mathrm{~g} \mathrm{I}_{2} 100 \mathrm{~g}^{-1}$ \\
Peroxide value & $10.00 \mathrm{meqkg}^{-1}$ \\
Free fatty acid & $2.48 \mathrm{mg} \mathrm{KOHg}^{-1}$ \\
Acid value & $5.02 \mathrm{mg} \mathrm{KOHg}^{-1}$ \\
\hline
\end{tabular}

Table 3 : Mineral element composition $\left(\mathrm{mg} 100 \mathrm{~g}^{-1}\right)$ of snake gourd

Element

Potassium

Sodium

Calcium

Magnesium

Zinc

Iron

Copper

Lead

Cobalt

Manganese

Phosphorus

\section{Concentration}

$121.60 \pm 6.5$

$74.66 \pm 13.6$

$27.62 \pm 1.2$

$79.12 \pm 2.2$

$87.25 \pm 9.3$

$4.31 \pm 0.31$

$0.31 \pm 0.01$

$1.30 \pm 0.02$

$0.32 \pm 0.01$

$0.31 \pm 0.06$

$135.0 \pm 1.2$

Mean+ standard deviations of triplicate determinations 
Table 4 : Functional properties of seed flour and protein concentrate

\begin{tabular}{lcc}
\hline Functional Property & Seed Flour & Protein Concentrate \\
\hline Oil Absorption Capacity(\%) & 54 & 115 \\
Water Absorption Capacity(\%) & 130 & 162 \\
Foaming Capacity (\%) & 47 & 78 \\
Gelation (LGC) \% & 18 & 30 \\
Emulsion Capacity(ml/g) & 450 & 690 \\
\hline
\end{tabular}

Table 5 : Effect of flour-solvent ratio on the solubilization and precipitation of snakegourd seed protein.

\begin{tabular}{llccc}
\hline Solvent & Flour-solvent & $\begin{array}{c}(\%) \text { Protein } \\
\text { solubilized }\end{array}$ & $\begin{array}{c}(\%) \text { Protein in } \\
\text { Whey }\end{array}$ & $\begin{array}{c}\text { (\%)Protein } \\
\text { precipitated }\end{array}$ \\
\hline $0.03 \mathrm{M} \mathrm{NaOH}$ & $1: 5$ & 79.92 & 28.68 & 71.32 \\
& $1: 10$ & 95.12 & 19.46 & 80.54 \\
& $1: 20$ & 80.73 & 25.52 & 74.48 \\
$0.03 \mathrm{M} \mathrm{Na}_{2} \mathrm{SO}_{3}$ & $1: 5$ & 65.44 & 39.53 & 60.47 \\
& $1: 10$ & 89.25 & 25.90 & 74.10 \\
& $1: 20$ & 77.15 & 34.90 & 65.10 \\
$0.03 \mathrm{M} \mathrm{Ca}(\mathrm{OH})_{2}$ & $1: 5$ & 66.13 & 33.73 & 66.27 \\
& $1: 10$ & 80.23 & 34.58 & 65.42 \\
& $1: 20$ & 78.45 & 38.48 & 61.53 \\
\hline
\end{tabular}

Values represent grand means of determinations 
Table 6 : Effect of extractant nature and concentration on the solubilization and precipitation of snakegourd seed protein.

\begin{tabular}{lcccc}
\hline Solvent & Conc. $(\mathbf{M})$ & $\begin{array}{c}(\%) \text { Protein } \\
\text { solubilized }\end{array}$ & $\begin{array}{c}(\%) \text { Protein in } \\
\text { Whey }\end{array}$ & $\begin{array}{c}(\%) \text { Protein } \\
\text { precipitated }\end{array}$ \\
\hline $\mathrm{NaOH}$ & 0.01 & 65.18 & 50.05 & 59.95 \\
& 0.02 & 78.35 & 40.25 & 69.75 \\
& & 0.03 & 95.12 & 19.4680 .54 \\
& 0.04 & 79.24 & 29.10 & 70.90 \\
$\mathrm{Na}_{2} \mathrm{SO}_{3}$ & 0.01 & 60.39 & 43.74 & 56.26 \\
& 0.02 & 64.83 & 39.99 & 60.01 \\
& 0.03 & 89.25 & 25.90 & 74.10 \\
& 0.04 & 76.20 & 36.67 & 63.33 \\
$\mathrm{Ca}(\mathrm{OH})_{2}$ & 0.01 & 65.22 & 35.82 & 64.18 \\
& 0.02 & 67.71 & 33.15 & 66.85 \\
& 0.03 & 80.23 & 34.58 & 65.42 \\
& 0.04 & 77.32 & 39.22 & 60.78 \\
\hline
\end{tabular}

Values represent grand means of determinations

Table 7 : Effect of extraction time on the solubilization and precipitation of snakegourd seed protein.

\begin{tabular}{lcccc}
\hline Solvent & Time $(\mathrm{min})$ & $\begin{array}{c}(\%) \text { Protein } \\
\text { solubilized }\end{array}$ & $\begin{array}{l}(\%) \text { Protein in } \\
\text { Whey }\end{array}$ & $\begin{array}{c}(\%) \text { Protein } \\
\text { precipitated }\end{array}$ \\
\hline $0.03 \mathrm{M} \mathrm{NaOH}$ & 10 & 89.28 & 22.76 & 77.24 \\
& 20 & 95.00 & 19.45 & 80.55 \\
& 30 & 90.11 & 24.65 & 75.35 \\
$0.03 \mathrm{M} \mathrm{Na}_{2} \mathrm{SO}_{3}$ & 10 & 86.72 & 31.15 & 68.45 \\
& 20 & 81.32 & 32.70 & 67.30 \\
& 30 & 89.01 & 25.89 & 74.11 \\
& 60 & 85.24 & 29.90 & 70.10 \\
$0.03 \mathrm{MCa}(\mathrm{OH})_{2}$ & 10 & 80.19 & 38.71 & 61.29 \\
& 20 & 74.25 & 43.26 & 56.74 \\
& 30 & 80.02 & 43.29 & 65.41 \\
& 60 & 75.22 & 40.81 & 59.91 \\
& 70.18 & 49.80 & 50.20
\end{tabular}

Values represent grand means of determinations 
Table 8 : Effect of flour treatment on the solubilization and precipitation of snakegourd seed protein.

\begin{tabular}{llccl}
\hline Solvent & Sample & $\begin{array}{c}(\boldsymbol{\%}) \text { Protein } \\
\text { Solubilized }\end{array}$ & $\begin{array}{l}(\%) \text { Protein in } \\
\text { Whey }\end{array}$ & $\begin{array}{l}(\%) \text { Protein } \\
\text { Precipitated }\end{array}$ \\
\hline $0.03 \mathrm{M} \mathrm{NaOH}$ & Undefatted & 95.00 & 19.45 & 80.55 \\
& Defatted & 95.12 & 19.46 & 80.54 \\
$0.03 \mathrm{M} \mathrm{Na}_{2} \mathrm{SO}_{3}$ & Undefatted & 89.01 & 25.89 & 74.11 \\
& Defatted & 89.25 & 25.90 & 74.10 \\
$0.03 \mathrm{M} \mathrm{Ca}(\mathrm{OH})_{2}$ & Undefatted & 80.02 & 34.59 & 65.41 \\
& Defatted & 80.23 & 34.59 & 65.42 \\
\hline
\end{tabular}

\section{REFERENCES}

Abbey, B. W. and Ibeh, G. O. (1988). Functional properties of raw and heat processed cowpea(Vigna unguiculata Walp) flour. J. Food Sci.,53, 1775-7, 1799.

Achinewhu, S. C. (1983). Chemical and Nutrient composition of fermented products from plant foods. Nig. Food J. p115 - 117 .

A.O. A. C. (1984). Official Methods of Analysis 14th Ed. Association of Official Agricultural Chemists, Washington, D. C.

Beuchat, L. R. (1977). Functional and electrophoretic characteristics of succinylated peanut flour proteins J. Agric. Food Chem. 25, 258-261.

Beuchat, L. R., Cherry, J. P. and Ouinn, M. R. (1975) Physicochemical properties of peanut flour as affected by proteolysis. J. Agric. Food Chem. 23, 616-620.

Cheftel, J. C. Cuq, J. L. and Lorient, I. (1989). Modificaciones del valor nutrionaly electos toxicos and propiedades functionales de las protainas: In J. F. Cheftel (ed). Protanas
Alimeritarias, Bioqumica propiedades functionales. Valor nutritiro. Modificacumes anumicas. Acribia, S. A. Zaragoza.

Coffman, C. W. and Garcia, V. V.(1977). Functional properties and amino acid content of a protein isolate from mung bean flour. J. Food Technology, 12, 473-484.

Dupriez, H. and De-Leener, P. (1989). Land and Life . African Garden and Orchard. Growing vegetables and fruits. Macmillan Publishing Ltd, London and Basingstoke.

FAO, (1982). Legume in Human Nutrition, Energy and selected Nutrients in Legumes Tables: Essential Amino Acid composition of Legume, Percentages of sugar and starch content of some whole legume flours. Protein Advisory Group.

Fleming, S. E., Sosulki, F. W. and Hamon, N. W. (1975). Gelation and thickening phenomena of vegetable protein products. J. Food Sci., 40, 805-807.

Grahams, D. F. and Phillips, M. C. (1976). Foams Food Ankes, R. J. Academic Press, London. 
Ige, M. M., Ogunsua, A. O. and Oke, L. O. (1984). Functional properties of some Nigerian Oil seeds. Conophor seeds and three varieties of melon seeds. J. Agric Food Chem. 32, 822-825.

Lawhon, J. T., Cater, C. M. and Mattil, K. F. (1972). A comparative study of the whipping potential of an extract from several oil seed flours. Cereal Science Today 17, 240-246.

Lin, M. J. V., Humbert, E. S. and Sosulski, F. W. (1974). Certain functional properties of sunflower meal products. J. Food Sci, 39, 368370.

Martin. F. W. (1987). CRC Handbook of Tropical Food Crops, Florida CRS

Press Inc. p $210-221$.

Olaofe, O., Umar, Y. O. and Adeniran, G. O. (1993). The effect of nematicides on the nutritive value and functional properties of cowpea seeds. Food. Chem. 64, 337 - 342.

Olaofe, O., Adeyemi, F. O. and Adeniran, G. O. (1994). Amino Acid and Mineral composition and functional properties of some oil seeds. J. Agric Food. Chem. 42, 878 - 881 .
Oshodi, A. A. and Ekperigin, M. M. (1989). Functional properties of pigeon pea (Cajanus cajan) flour. Food Chem. 15, 216-221.

Osagie, A. U. and Odutuga, A. A. (1986). Chemical characterisation and edibility of the oils extracted from four Nigerian oil seeds. Nig. J. Pure and Appl Sci. 1, 35-42. Pomeranz, V and Chifton, E. (1981). Food Analysis. Theory and Practice. Meloan E. Ed. AVI publishing company TIC West Port, Connecticut, USA.

Romanatham, G., Ran, L. H. and Urs, L. N. (1978). Emulsification properties of groundnut protein. J. Food Sci. 43, 1270-1273.

Rosario, R. R. and Flores, D. M. (1981). Functional properties of four types of mung bean flours. J. Sci. Food Agric, 32, 175-180.

Siemonsma, J. S. and Piluck, K. (1993). Plant Resources of South East Asia No 8 Vegetable Pudoc Scientific Publishers, Wageningen.

Tindall, H. D. (1983). Vegetables in the Tropics. Macmillan Press, London. p 5 - 7.

Smith, A. K. and Circle, S. J. (1972). Soybeans: Chemistry and Technology. Vol. 1, AVI Publishing Company Inc. West Port, Connecticut, USA . 